\title{
Popularização da Ciência: Desmistificando o Dogma Central da
}

\section{Biologia Molecular}

\author{
Popularization of Science: Demystifying the Central Dogma of Molecular Biology
}

\begin{abstract}
Laura Raniere Borges dos Anjos ${ }^{1,2}$, Leandro do Prado Assunção ${ }^{1}$, Bruno Lima Freitas ${ }^{1}$, Nawyla Pereira Campos ${ }^{1}$, Natalia Sousa Silva ${ }^{1}$, João Marcos Araújo Monteiro', Renata Alves Oliveira', Geovana Santana Rodrigues ${ }^{1}$, Rayane Oliveira Cruz Veríssimo ${ }^{1}$, Sabrina Fonseca Ingênito Moreira Dantas ${ }^{1}$, Mônica de Oliveira Santos ${ }^{1}$, Angela Adamski da Silva Reis², Rodrigo da Silva Santos ${ }^{2}$
\end{abstract}

${ }^{1}$ Instituto de Ciências da Saúde (ICS) da União das Faculdades Alfredo Nasser (UNIFAN), Aparecida de Goiânia,

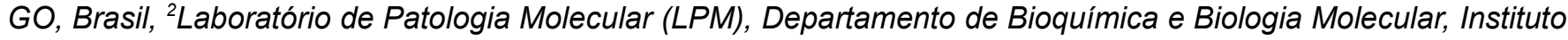
de Ciências Biológicas (ICB II), Universidade Federal de Goiás (UFG), Goiânia, GO, Brasil.

*e-mail: rdssantos@gmail.com (R.S.S - Coordenador do Projeto)

\section{Resumo}

Esse projeto de extensão foi apresentado durante a XII Edição do Movimento Científico e Cultural de Aparecida de Goiânia, Goiás, Brasil (MOCCA). O objetivo foi promover o conhecimento científico básico sobre o fluxo da informação genética a partir da experimentação por métodos ilustrativos. Cada participante respondeu um questionário para avaliar seu conhecimento prévio sobre o tema. Em seguida, foi direcionado a um monitor que o acompanhava, no ambiente interativo, apresentando ilustrações com maquetes, painéis, modelos tridimensionais, bem como, na realização da extração simples de DNA de uma fruta. Ao final, o mesmo questionário foi reaplicado. A análise comparativa do desempenho dos participantes no questionário antes e depois da realização das atividades mostrou que as abordagens interativas e as práticas ilustrativas contribuíram, positivamente, para a melhor compreensão do conteúdo sugerindo que essa metodologia possa ser incorporada ao processo de ensinoaprendizagem.

Palavras-chave: Biologia Molecular; Dogma Central; Informação Genética

\begin{abstract}
This extension project was presented during the XII edition of the Cultural and Scientific Movement of Aparecida de Goiânia, Goiás, Brazil (MOCCA). The objective was to promote the basic scientific knowledge on the flow of genetic information from experimentation by illustrative methods. Each participant answered a questionnaire to assess their prior knowledge of the topic. He was then directed to a monitor that accompanied him, through the interactive environment, presenting illustrations with models, panels, three-dimensional models, as well as the accomplishment of the simple extraction of DNA from a fruit. At the end, the same questionnaire was reapplied. The comparative analysis of the participant's performance in the questionnaire before and after the activities showed that interactive and illustrative practical approaches contributed positively to the better understanding of the content suggesting that this methodology can be incorporated into the teaching-learning process.
\end{abstract}

Keywords: Molecular Biology; Central Dogma; Genetic Information 


\section{Introdução}

A construção do conhecimento científico relacionado a ciências biológicas vem sofrendo modificações significativas ao longo do tempo, principalmente porque muitas descobertas aconteceram no século XX e XXI. Até então, essa área do conhecimento era abordada a partir da disciplina nomeada, no nível fundamental e médio, como ensino de ciências e biologia, respectivamente. Em ambas disciplinas, as aulas restringiam-se a apresentações de conceitos gerais sobre grupos isolados de plantas, animais e outros seres vivos. Fundamentada em valores que visavam uma contribuição sociocultural em detrimento ao conhecimento científico, temas mais específicos não eram abordados dentro das salas de aula [1].

Acompanhando forte tendência mundial, no período de 1950 a 1970, o Brasil vivenciou uma reforma no ensino de ciências que impulsionou a pesquisa e, também, modificou a abordagem educacional no ensino de biologia. Nesse contexto, o ensino de biologia tornou-se mais profundo e integrado com outras áreas. Essa nova visão associada às inovações tecnológicas e à implantação de programas de pesquisa em ciências estimularam professores, pesquisadores e diversos profissionais vinculados ao ensino à realização de debates e discussões nas mais diversas esferas e níveis educacionais [2].

Essa interação acadêmico-científica culminou na elaboração de novos materiais de apoio aos docentes de ensino fundamental e médio que, até então, contavam apenas com versões traduzidas de outras culturas que não correspondiam às necessidades do país naquele momento. Na tentativa de melhor atender a essa nova proposta educacional e científica, a biologia foi subdividida em extensões específicas que passaram a ser investigadas e abordadas na pesquisa e dentro do próprio ensino de ciências [3].

As pesquisas avançaram na área da genética clínica e biologia molecular e desencadearam uma explosão do conhecimento biológico. Rapidamente assuntos como o funcionamento e a importância do material genético na transmissão de características hereditárias, a descoberta e localização dos genes que predispõem a formação de tumores, o uso terapêutico das células-tronco, clonagem, mutações, transgênicos, projeto genoma e teste de paternidade tornaram-se pautas de discussões cotidianas em todos os níveis sociais [4].

Desde então, esses temas são continuamente vinculados pela mídia, internet e abordados em sala de aula, no entanto, essa popularização da ciência nem sempre está bem fundamentada ou conceituada, o que acaba incorrendo num conhecimento 
fragmentado, descontextualizado, superficial e muitas vezes com "concepções inadequadas" [2].

Esse panorama está na contramão do anseio por uma educação sólida e edificada a partir do conhecimento científico que atenda sem neutralidade, as inúmeras necessidades da sociedade contemporânea. A disseminação dessas informações superficiais potencializadas pelo excesso e facilidade de comunicação, deficiência na formação e/ou aperfeiçoamento de professores, bem como o déficit na qualidade de formação de estudantes e universitários são fatores que podem ser interferentes e intensificadores ao processo de sustentação dessa realidade contraposta [5].

Nesse aspecto percebe-se que a sociedade, na verdade, tornou-se refém de suas próprias ações, pois a construção de conhecimento insatisfatório é consequência do próprio contexto cultural e social que retroalimenta um ciclo improdutivo. Fica evidente que é indispensável uma mudança no atual perfil educacional e isso representa um desafio e desencadeia uma responsabilidade gradual para os ambientes e profissionais envolvidos com o processo educacional sejam eles pertencentes ao ensino regular ou universitário [6].

Considerando que há uma expectativa de expansão da biologia molecular, esta se torna uma ferramenta para uma melhor compreensão da vida, seus limites e possibilidades [7]. A biologia molecular descreve, de maneira geral, como os processos biológicos podem ser compreendidos a partir do conhecimento prévio estrutural das moléculas e suas respectivas interações e alterações. O Dogma Central da Biologia Molecular é o conteúdo chave para o entendimento desses aspectos e processos, no entanto, o contexto nacional mostra que, apesar de abordado dentro do ambiente educacional, o conhecimento significativo gerado é pouco ou quase nenhum quando se trata, em específico, da biologia molecular. Segundo Melo e Carmo (2009) [4], a biologia molecular é uma das disciplinas mais difíceis de serem trabalhadas tanto no Ensino Médio quanto no Superior, tendo em vista seu alto nível de abstração.

Para que essa sequência ressoante e ineficiente do atual sistema de ensinoaprendizagem em Biologia molecular seja rompida, novas estratégias de ensino devem ser desenvolvidas e aplicadas. É consenso entre os professores de Biologia que a utilização de abordagens práticas, dentro e fora da sala de aula, são de extrema importância e podem levar a uma inovação do atual ensino tradicional [8]. Segundo Souza et al (2014) [9], práticas que proporcionem o envolvimento dos estudantes e diferenciamse do modelo tradicionalista tornam o processo de ensino-aprendizagem mais dinâmico e 
efetivo.

Baseado nessas constatações, esse trabalho tem como objetivo relatar como a disponibilização de um ambiente dinâmico e interativo auxilia os alunos do ensino regular e universitário de escolas e instituições localizadas em Aparecida de Goiânia (Goiás, Brasil) e região metropolitana, na construção e na compreensão dos conceitos básicos sobre o fluxo de informação genética das células, postulado pelo Dogma Central da Biologia Molecular.

\section{Material e Métodos}

O presente trabalho foi desenvolvido na XII Edição do Movimento Científico e Cultural de Aparecida (MOCCA) realizado pela Faculdade Alfredo Nasser, em Aparecida de Goiânia, Goiás, Brasil, em parceria com a Universidade Federal de Goiás (UFG, Brasil). Com amostra de conveniência, a população de participantes foi baseada no comparecimento voluntário de estudantes do ensino básico (fundamental e médio de instituições públicas e privadas) e superior (graduação de instituição privada), ao laboratório de Microscopia I do Instituto de Ciências da Saúde (ICS), da União das Faculdades Alfredo Nasser (UNIFAN).

A etapa 1 do projeto consistiu em aplicar, aos estudantes voluntários, um questionário (Apêndice $A$ ), com objetivo de avaliar o perfil do conhecimento prévio dos alunos em relação ao conteúdo curricular envolvendo biologia molecular. Essa avaliação diagnóstica foi composta por 05 questões que estavam relacionadas com as definições de DNA, RNA, cromossomo, estruturas dos ácidos nucléicos e finalidade do processo de replicação do DNA.

$\mathrm{Na}$ etapa 2, foi realizada uma breve explicação sobre as principais técnicas e aplicações da biologia molecular: Reação em Cadeia da Polimerase (PCR), eletroforese, Southern Blot, Northern Blot e Western Blot. Em seguida, os alunos voluntários foram direcionados em atividades fundamentadas na utilização de materiais didáticos de apoio que relacionavam teoria e prática.

$\mathrm{Na}$ etapa 3, esses alunos passaram por um percurso interativo dividido em ambientes explicativos que continham maquetes, painéis, representações tridimensionais, demonstração de materiais/equipamentos que reproduziam a compactação do DNA dentro do núcleo da célula, estruturas simplificadas das moléculas de DNA e RNA, cromossomos, genes, cromatinas e conceitos básicos do Dogma Central da Biologia Molecular. Uma estrutura tridimensional, em particular, se destacou por representar a 
molécula de DNA, como descrito por Watson e Crick em 1952, com sua forma helicoidal e complementaridade de bases nitrogenadas. Essas bases nitrogenadas estavam representadas por balas de jujubas coloridas (Adenina = azul, Timina = amarelo, Citosina = vermelha, Guanina = verde). Essa estrutura, também, permitiu a identificação dos pareamentos por meio de ligações de hidrogênio que estavam representadas por palitos de pirulitos brancos (02 unidades representando as interações moleculares entre as bases nitrogenadas Timina e Adenina e 03 unidades representando as interações moleculares entre as bases nitrogenadas Citosina e Guanina).

$\mathrm{Na}$ etapa 4, painéis esquemáticos demonstraram a diferença estrutural entre as moléculas de DNA e RNA e os processos biológicos de replicação do DNA, transcrição do RNA e tradução ou síntese proteica.

$\mathrm{Na}$ etapa 5, foi realizada uma extração de DNA de um vegetal (Apêndice C adaptação do Protocolo do Centro de Estudos do Genoma Humano-USP) a partir do uso de produtos domésticos [10].

$\mathrm{Na}$ etapa 6, os visitantes responderam um questionário idêntico ao aplicado na etapa 1. O objetivo dessa metodologia foi traçar uma linha evolutiva alicerçada no conhecimento prévio e no conhecimento recém-adquirido durante a participação no projeto. Apesar dessa metodologia ter limitações e sugerir apenas indícios de aprendizagem, sua escolha justificou-se pelo curto tempo para realização do estudo associado a complexidade do conteúdo.

Por último, os visitantes, ainda, responderam outro questionário (Apêndice B) destinado a identificação do nível de qualidade do projeto "Popularização da Ciência: Desmistificando o Dogma Central da Biologia Molecular" e do evento principal "XII Movimento Científico e Cultural de Aparecida” (MOCCA-BRASIL).

\section{Resultados e Discussão}

A população de participantes foi composta por 51 voluntários. Todos preencheram o questionário da etapa 1 e 6 . O perfil acadêmico dos estudantes era composto por alunos do Ensino Básico (60,78\%), Ensino Superior (29,41\%) e 9,80\% não informaram o seu nível de instrução. Essa diversidade nos níveis de ensino proporcionou uma avaliação heterogênea quanto ao método interativo utilizado.

No primeiro item do questionário, desejava-se saber a definição de DNA. Inicialmente, $45,10 \%$ dos alunos responderam ácido desoxirribonucleico e 54,90\% optaram por outra alternativa (ácido ribonucleico, proteína, dor nas articulações). 
Entretanto, após passarem pelo método de ensino interativo a taxa de discentes que responderam corretamente aumentou para $80,49 \%$, sugerindo que esta abordagem é eficaz para o aprendizado dos alunos (Figuras 1A e 1B).
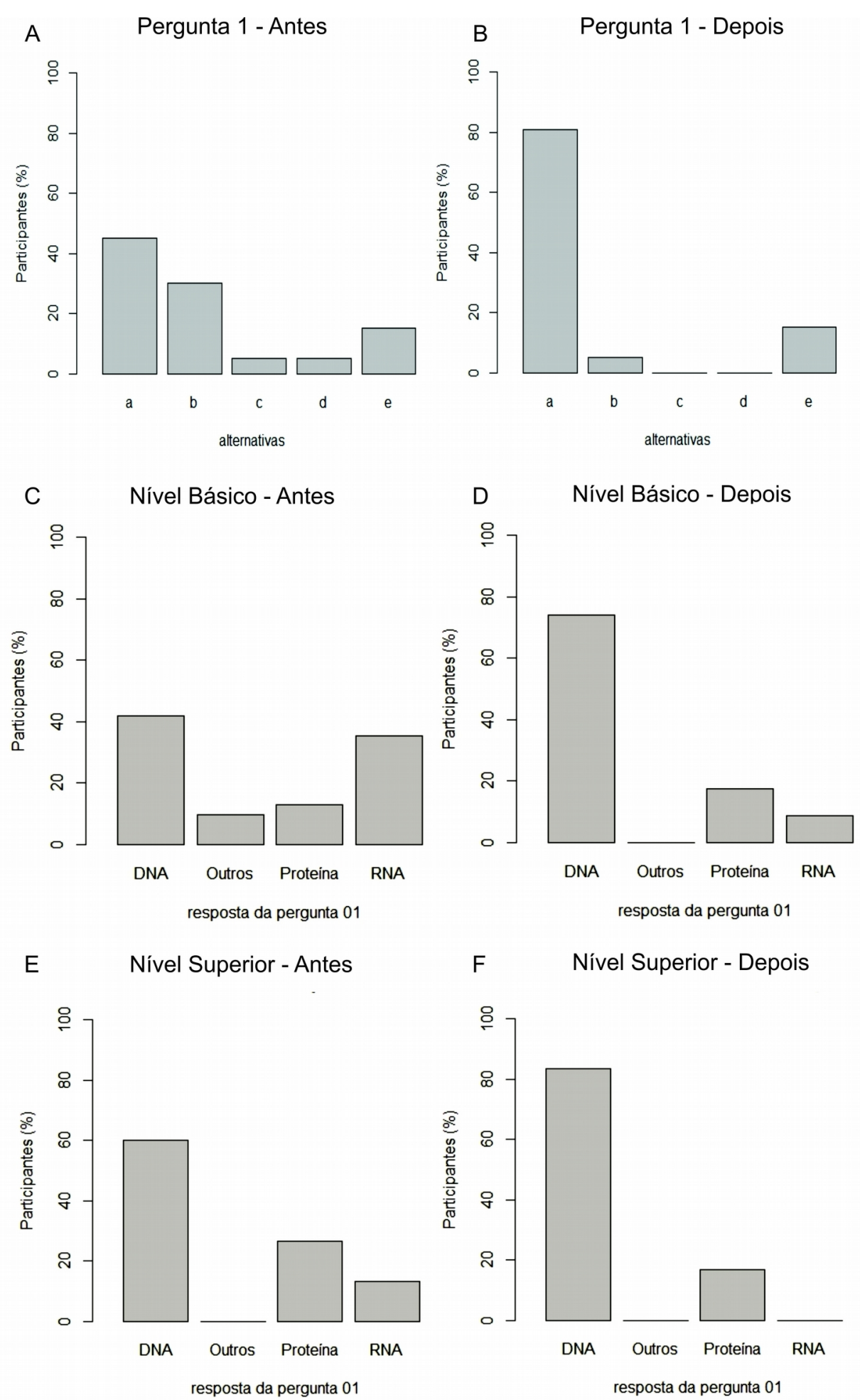

Figura 1. A) Desempenho Geral dos visitantes na pergunta 01 do questionário, antes da visitação: a) Ácido desoxirribonucleico, b) Ácido Ribonucleico, c) Dor nas Articulações, d) Outros, e) Proteína; B) Desempenho Geral dos visitantes na pergunta 01 do questionário, depois da visitação: a) Ácido desoxirribonucleico, b) Ácido Ribonucleico, c) Dor nas Articulações, d) Outros, e) Proteína; C) Desempenho dos visitantes de nível básico antes da visitação; D) Desempenho dos visitantes de nível básico depois da visitação; E) Desempenho dos visitantes de nível superior antes da visitação; F) Desempenho dos visitantes de nível superior após a visitação. 
É preciso destacar que o aumento de respostas assertivas após a visitação foi maior entre os alunos do ensino básico do que entre alunos do ensino superior (Figuras 1C-D - 1E-F). O aumento de acertos entre os participantes do ensino básico alcançou $72,84 \%$, enquanto no ensino superior o aumento registrado foi de $41,96 \%$. Esse aumento não pode ser atribuído restritamente a um maior aproveitamento pelo grupo de visitantes do ensino básico.

É preciso levar em consideração que os visitantes do ensino superior já tinham apresentado um bom desempenho no questionário que verificava o nível de conhecimento prévio e, portanto, nesse grupo o bom desempenho apenas se manteve constante. Outro fato que influencia essa análise é o tamanho da amostra de ensino superior que, por ser uma amostra de conveniência, foi relativamente pequena.

Objetivou-se na pergunta 02 identificar quantos visitantes conheciam qual ácido nucleico caracteriza-se por ser uma molécula de fita simples. Os resultados mostraram que $50,98 \%$ dos visitantes responderam corretamente a esse item antes da visitação. Após a participação do projeto esse índice de acerto subiu para 78,05\% (Tabela 1).

Destaca-se que, antes da visitação, todas as alternativas foram escolhidas pelo menos uma vez: Cromossomo (11,76), DNA (11,76\%), Gene (9,8\%), Mitocôndria $(9,8 \%)$, RNA (50,98\%) e 5,88\% não responderam (NR). Diferentemente do que ocorreu após os alunos terem participado do método de ensino proposto, onde a proporção de escolha para essas alternativas limitaram-se em DNA (14,63\%), Mitocôndrias $(7,32 \%)$ e RNA (78,05\%).

A mudança de opinião dos alunos nas perguntas 01 (Figuras 1A-F) e 02 (Figuras $2 \mathrm{~A}$ e $2 \mathrm{~B}$ ) após a visitação do projeto reafirma a hipótese de que métodos práticos, em que o professor atua como um facilitador, tornam o processo ensino-aprendizagem mais eficaz $[9,10,11]$. Alunos do ensino básico apresentaram maior dificuldade na pergunta $2 \mathrm{e}$ isso fica implícito na diversidade de respostas escolhidas (Cromossomo, DNA, Gene, Mitocôndrias, RNA). 


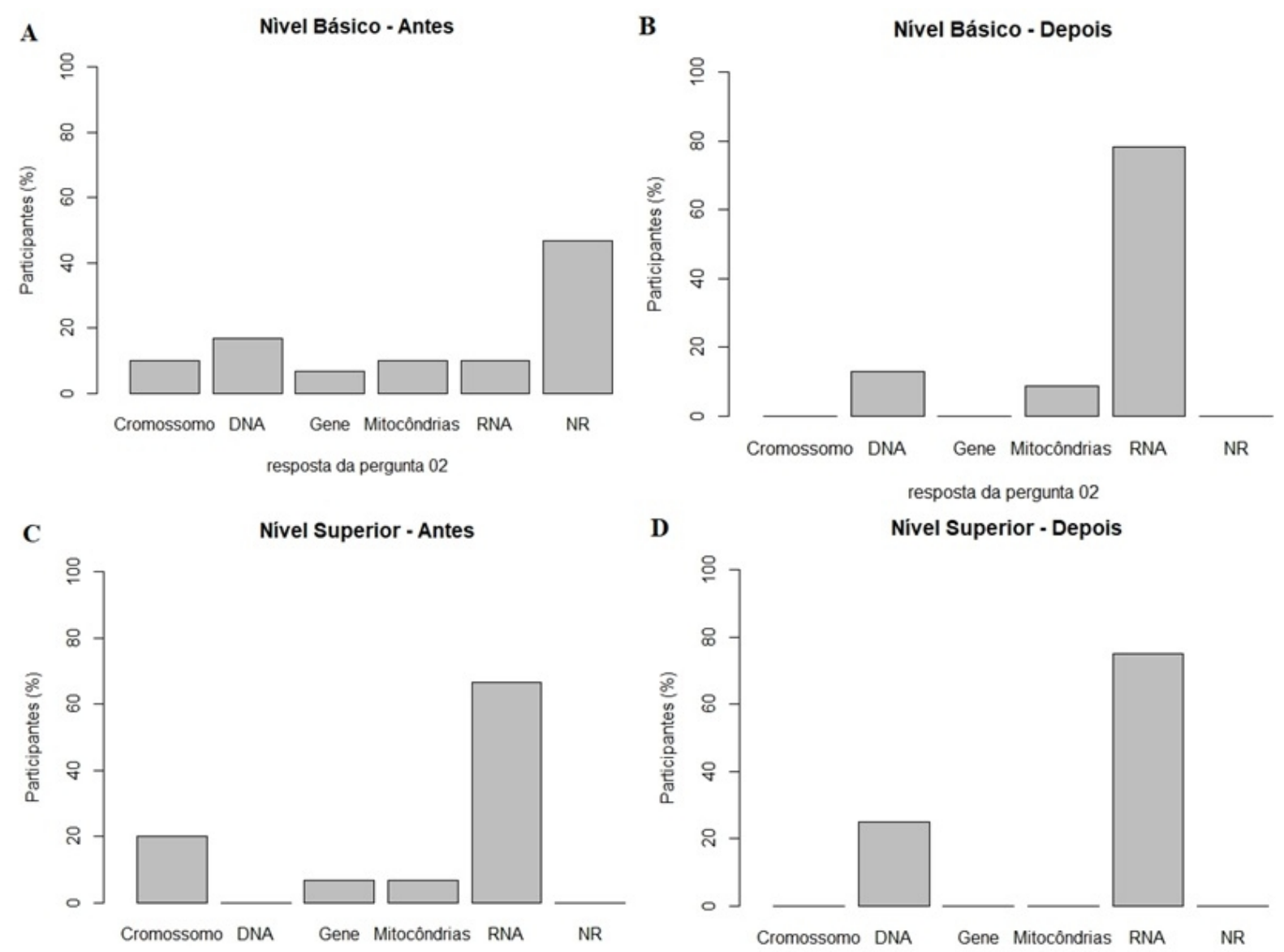

Figura 2. Desempenho dos visitantes na pergunta 02 do questionário (antes e depois). NR: não responderam.

Os alunos do ensino superior demonstraram maior domínio do conteúdo, o que fica claro quando $66,67 \%$ e 75\% desses alunos optaram pela alternativa "RNA" antes e após a visitação do projeto, respectivamente (Tabela 1). Sugere-se que essa grande diversidade de resposta entre os alunos do ensino básico novamente relaciona-se com a falta de contato com o conteúdo, o que não acontece entre alunos do ensino superior. Visitantes do ensino superior, principalmente das áreas da saúde e biológicas, tem contato direto com o tema abordado tanto a nível teórico quanto prático.

Tabela 1. Frequência relativa das alternativas escolhidas pelos alunos de ensino superior que visitaram o projeto

\begin{tabular}{ccc}
\hline Alternativas da Pergunta 2 & Antes \% & Depois \% \\
\hline Cromossomo & 20 & 0 \\
DNA & 0 & 25 \\
Gene & 6,67 & 0 \\
Mitocôndrias & 6,67 & 0 \\
RNA & 66,67 & 75 \\
\hline
\end{tabular}


Segundo Freire (1997), para se compreender uma teoria é preciso experiênciá-la. A realização de experimentos representa uma excelente técnica para que o aluno construa um significado para o conteúdo. Outros pesquisadores também afirmam que a experimentação é essencial para o ensino da ciência, melhorando o pensamento crítico dos alunos, além de ultrapassar em qualidade e eficiência de aprendizado os métodos tradicionais de memorização [12].

As perguntas 03 e 04 tinham o objetivo de avaliar o conhecimento dos alunos em biologia celular e molecular básica. O perfil de respostas dos alunos, antes e após a aplicação da metodologia proposta, foi muito semelhante para a questão 3 (Tabela 2). Mesmo o conteúdo partindo para campo da abstração, os alunos obtiveram um bom desempenho, no qual podemos destacar que a parte prática do projeto realizado durante o MOCCA contribuiu para a visualização das moléculas de DNA e RNA.

Tabela 2. Frequência absoluta das respostas da pergunta 03.

\begin{tabular}{|c|c|c|c|c|c|c|c|}
\hline \multirow{2}{*}{ Fatores } & \multirow{2}{*}{ Alternativas } & \multicolumn{6}{|c|}{ Frequência absoluta } \\
\hline & & a & b & C & d & e & f \\
\hline \multirow{3}{*}{ Antes } & Falso & 32 & 7 & 21 & 9 & 3 & 15 \\
\hline & Outros* & 10 & 11 & 11 & 12 & 12 & 12 \\
\hline & Verdadeiro & 9 & 33 & 19 & 30 & 36 & 24 \\
\hline \multirow{3}{*}{ Depois } & Falso & 40 & 3 & 37 & 4 & 5 & 10 \\
\hline & Outros* & 3 & 3 & 3 & 3 & 3 & 3 \\
\hline & Verdadeiro & 8 & 45 & 11 & 44 & 43 & 38 \\
\hline
\end{tabular}

a. Cada cromossomo contém apenas um gene. b. A estrutura do DNA consiste em uma longa dupla hélice e o RNA em uma fita única simples. c. Moléculas de RNA são constituídas por duas cadeias de nucleotídeos enroladas uma sobre a outra, a chamada "dupla hélice". d. O DNA é uma molécula que transmite a informação genética e tem a capacidade de se autoduplicar. e. Uma cópia de DNA é passada para a célula filha durante a divisão celular. f. Cada molécula de DNA contém vários "genes" dispostos linearmente ao longo da molécula.

* Participantes que marcaram $X$ em um ou vários itens e não entenderam que era uma questão de $V$ ou $F$.

Isso sugere que métodos práticos, tais como painéis esquemáticos e aulas práticas interativas, podem auxiliar no aprendizado dos alunos. O que corrobora com os estudos realizados por Oliveira (2013) [13] que afirma que as pessoas aprendem de diversas formas. Há alunos que aprendem por meio da audição (comunicação oral e atenção à aula expositiva), outros por meio visual (precisam ver a imagem), e os cinestéticos que aprendem interagindo e participando.

Essa metodologia também contribuiu para compreensão quanto à estrutura física da molécula de DNA abordada pela questão 05. Dado as teorias de educação fundamentadas na importância da vivência prática a cerca dos conteúdos abordados em sala de aula [14], percebe-se que a extração do DNA de células vegetais, utilizando produtos domésticos, foi uma forma positiva de associar a prática com o conteúdo abordado e que os resultados foram satisfatórios ao observar-se aumento considerável na escolha da resposta correta após a participação do projeto (Figuras 3A e 3B). 

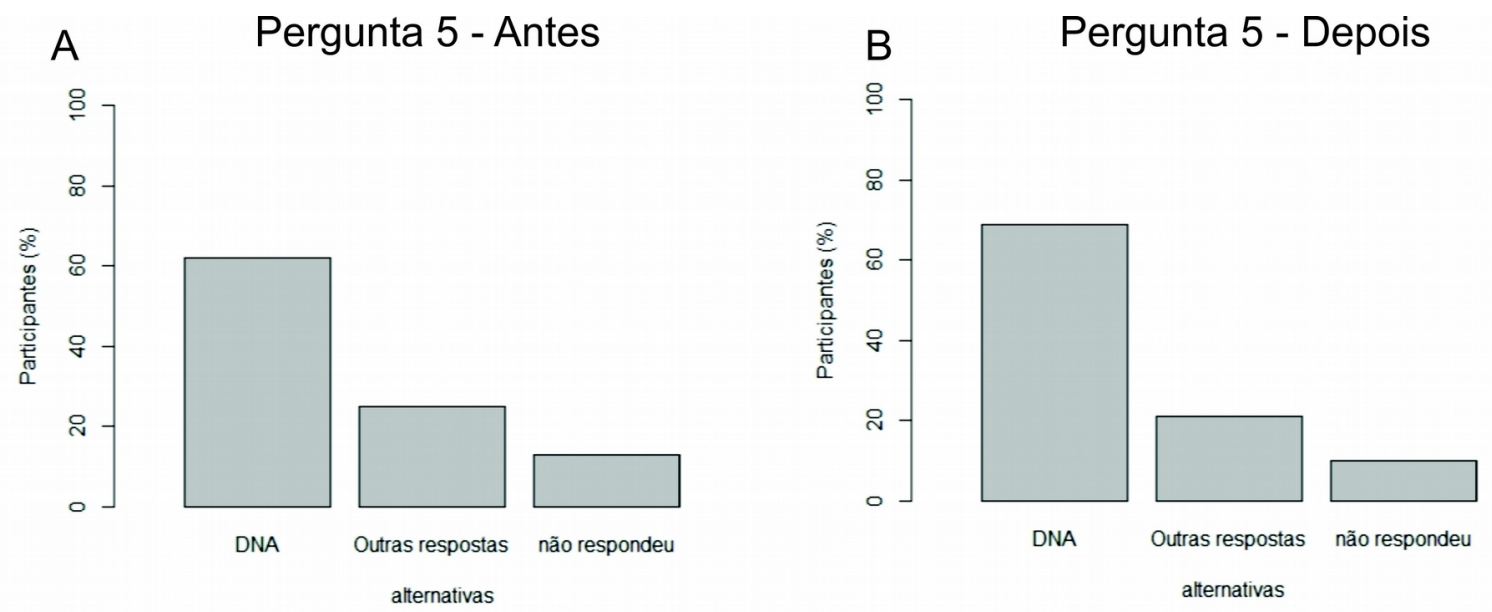

Figura 3. Desempenho dos visitantes na pergunta 05 do questionário (Frequência relativa)

Durante a análise da estrutura física do DNA, percebe-se que a maioria dos visitantes tinham conhecimento da estrutura tridimensional da molécula, mas mesmo assim ocorreu um aumento, de aproximadamente $6 \%$, no grupo dos que responderam corretamente essa pergunta. Sendo assim, sugere-se que o método utilizado de construção da molécula de DNA artificial, com materiais comuns, facilitou a compreensão do aluno.

Estudos realizados por Souza e colaboradores (2014) afirmam que os jovens sentem muita facilidade em coordenar as informações visuais e sonoras provenientes de múltiplas perspectivas, espaço-temporais, de realidade e imaginário. Além disso, visitantes que são expostos a métodos interativos apresentam autonomia intelectual durante os estudos. Diferentemente dos métodos tradicionais, modelo de ensino centrado no professor, em que o aluno se torna totalmente dependente do professor no âmbito de aprendizagem [9].

Os dados obtidos no MOCCA corroboram com os dados obtidos do questionário avaliativo, uma vez que a maior parte dos visitantes avaliaram o projeto de forma positiva. Essa alta taxa de aprovação pelos alunos destaca-se sobretudo no item 2 do formulário de avaliação do projeto, quando os visitantes (70,73\%) informaram que o método abordado foi determinante no aprendizado da Biologia Molecular (Tabela 4).

As respostas das questões 3,4 e 5 do formulário avaliativo também apresentam associação com o alto desempenho dos alunos após a participação dos métodos interativos do projeto MOCCA. Percebe-se que aproximadamente $29,27 \%$ dos alunos antes da participação do projeto nunca haviam tido contato com a biologia molecular. Além disso, $31,71 \%$ dos visitantes que afirmaram terem visto biologia molecular pelo menos uma vez, nunca teve aula prática dessa disciplina. 
Esses dados concordam com os resultados apresentados anteriormente, onde houve um aumento de respostas corretas após aplicação do método interativo. Entretanto, observa-se a falta de estrutura das escolas e universidades, uma vez que o conteúdo básico de biologia molecular está presente na grade curricular dos cursos de nível básico, e no ensino superior, em cursos de biológicas, é matéria obrigatória. Durante o projeto, percebe-se que a maioria dos visitantes aprovaram a nova metodologia e quando foi perguntado se eles retornariam em extensões posteriores ou novos projetos, em torno de $58,54 \%$ dos visitantes responderam que sim (Tabela 3 ).

Tabela 3 - Avaliação dos alunos sobre o projeto

\begin{tabular}{cccc}
\hline Itens/respostas & Sim \% & Não \% & Não respondeu \% \\
\hline 1 & 70,73 & 0,00 & 29,27 \\
2 & 70,73 & 0,00 & 29,27 \\
3 & 68,29 & 2,44 & 29,27 \\
4 & 39,02 & 31,71 & 29,27 \\
5 & 41,46 & 29,27 & 29,27 \\
6 & 58,54 & 9,76 & 31,71 \\
7 & 63,41 & 7,32 & 29,27
\end{tabular}

1. Você gostou de visitar o Projeto?. 2. Considera que a visita ao Projeto contribuiu para seu aprendizado?. 3. Considera que atividades práticas facilitam/melhoram o entendimento dos conteúdos? 4. Sua escola/faculdade proporciona aulas práticas sobre Biologia Molecular? 5. Já teve contato com a Biologia Molecular antes do Projeto?. 6. Participaria outra vez do Projeto?. 7. Participaria outras vezes do MOCCA?

\section{Considerações Finais}

Os resultados deste estudo corroboram e reforçam o que já vem sendo descrito na literatura científica, onde sugere-se que é importante repensar a atual forma de ensino. Escolas do ensino médio e instituições de ensino superior devem buscar métodos interativos de aprendizagem que visem estimular mais os alunos a participarem das aulas e, consequentemente, obterem resultados satisfatórios em relação ao processo de construção do saber.

Considerando os resultados satisfatórios obtidos com o Projeto de Extensão: Popularização da Ciência: Desmistifcando o Dogma Central da Biologia Molecular, disponibilizado durante a XII edição do Projeto social "Movimento Científico e Cultural de Aparecida" (MOCCA) realizado pela Faculdade Alfredo Nasser, em parceria com a Universidade Federal de Goiás (UFG), pode-se dizer que métodos práticos e dinâmicos são boas sugestões para essa nova abordagem, porém novos estudos se fazem necessários, de forma a disponibilizar dados qualitativos, utilizando-se grupos controles, os quais deverão ter contato com os mesmos conteúdos em um ambiente de ensinoaprendizagem comum, como a sala de aula, num processo expositivo, por exemplo. 


\section{Referências}

[1] OLIVEIRA, P. S. de; NASCIMENTO, M. C; BIANCONI, L. M. Mudanças conceituais ou comportamentais?. Ciência e Cultura, v.57, n.4, Out/Dez, 2005, Disponível em: http://cienciaecultura.bvs.br/ pdf/cic/v57n4/a24v57n4.pdf. Acesso em: 15 de Junho de 2016.

[2] KRASILCHIK, M. Reformas e realidades: o caso de ensino das ciências. São Paulo em perspectiva, v.14, n.1, São Paulo, Jan/Mar, 2000. Disponível em: http://www.scielo.br/pdf/spp/v14n1/9805.pdf. Acesso em: 16 de Junho de 2016.

[3] RAMOS, M. B. J.; FARIA, E. T. Aprender e ensinar diferentes olhares e práticas. Pontifícia Universidade Católica do Rio Grande do Sul, EdiPUCRS, 2011. Disponível em: http://ebooks.pucrs.br/edipucrs/Ebooks/Pdf/978-85-397-0076-9.pdf. Acesso em: 16 de Julho de 2016.

[4] MELO, J. R ; CARMO, E. M. Investigações sobre o ensino de genética e Biologia Molecular no Ensino Médio Brasileiro: reflexões sobre as publicações científicas. Ciência e Educação, v.15, n.3, p.593-611,2009. Disponível em: http://www.scielo.br/pdf/ciedu/v15n3/09.pdf. Acesso em: 20 de Julho de 2016.

[5] RAZERA, J. C. C; NARDI, R. Ensino de Ciências e Educação Moral. Cultura Acadêmica, Universidade Estadual Paulista, Editora UNESP, p.258, São Paulo, 2009. Disponível em: http://books.scielo.org/id/g5q2h/pdf/nardi-9788579830044-05.pdf. Acesso em: 25 de Setembro de 2016.

[6] VELASCO, J; ODDONE, N. O livro eletrônico na prática científica: estratégia metodológica. Anais do VIII ENANCIB - Encontro Nacional de Pesquisa em Ciência da Informação - UFBA, out, 2007. Disponível em: http://enancib.ibict.br/index.php/enancib/viiienancib/paper/viewFile/2943/2070. Acesso em: 25 de Setembro de 2016.

[7] BATISTETI, C. B; ARUJO, E. S. N; CALUZI, J. J. A formação de conceitos no ensino de biologia e química. Cultura Acadêmica, Universidade Estadual Paulista, Editora UNESP, p.287, São Paulo, 2009. Disponível em: http://books.scielo.org/id/htnbt/pdf/caldeira-9788579830419-04.pdf. Acesso em: 20 de Agosto de 2016.

[8] MARTINS, L. A. P. História da Ciência, objetos, métodos e problemas. Ciência e Educação, (Bauru), v.11, n.2, p.305-317, Bauru, Mai/Ago, São Paulo, 2005. Disponível em: http://www.scielo.br/pdf/ciedu/v11n2/10.pdf. Acesso em: 20 de Agosto de 2016.

[9] SOUZA, C. S; IGLESIAS, A. G; FILHO, A. P. Estratégias inovadoras para métodos de ensino tradicionais - aspectos gerais. Simpósio: Tópicos fundamentais para a formação e o desenvolvimento docente para professores dos cursos da área da saúde - Ribeirão Preto, v.47, n.3, Jul/Set, 2014. Disponível em: http://revista.fmrp.usp.br/2014/vol47n3/6_Estrategias-inovadoras-para-metodos-de-ensino-tradicionaisaspectos-gerais.pdf. Acesso em: 20 de Setembro de 2016.

[10] DESSEN, E.M.B; OYAKAWA, J. Extração Caseira de DNA Morango: Protocolo do Centro de Estudos do Genoma Humano-USP. Centro de Estudos do Genoma Humano- USP. 2015. Disponível em, http://www.genoma.ib.usp.br/sites/default/files/protocolos-de-aulas-praticas/ extracao_dna_morango_web1.pdf> Acesso em: 20 de setembro de 2016.

[11] BAZIN, M. (1987). Three years of living science in Rio de Janeiro: learning from experience. Scientific Literacy Papers, 67-74. Brasil. (1998). Secretaria de Educação Fundamental. Parâmetros curriculares nacionais: Ciências Naturais/Secretaria de Educação Fundamental. Brasília: MEC/SEF.

[12] FREIRE, P. Pedagogia da Autonomia. Rio de Janeiro: Paz e Terra, 1997.

[13] ROSITO, B. A. O Ensino de Ciências e a Experimentação. In: MORAES, R. (org.). Construtivismo e Ensino de Ciências: Reflexões Epistemológicas e Metodológicas. Porto Alegre: EDIPUCRS, 2008.

[14] OLIVEIRA, T.T. Uso de TICs no Ensino de Biologia: Um olhar docente. Monografia apresentada para obtenção de título de especialista. Universidade Tecnológica Federal do Paraná. Diretoria de Pesquisa e Pós-Graduação. Especialização em Educação: Métodos e Técnicas de Ensino. 2013. 
Apêndice A. Questionário destinado à pesquisa do projeto: "Popularização da ciência: desmistificando o dogma central da Biologia molecular.
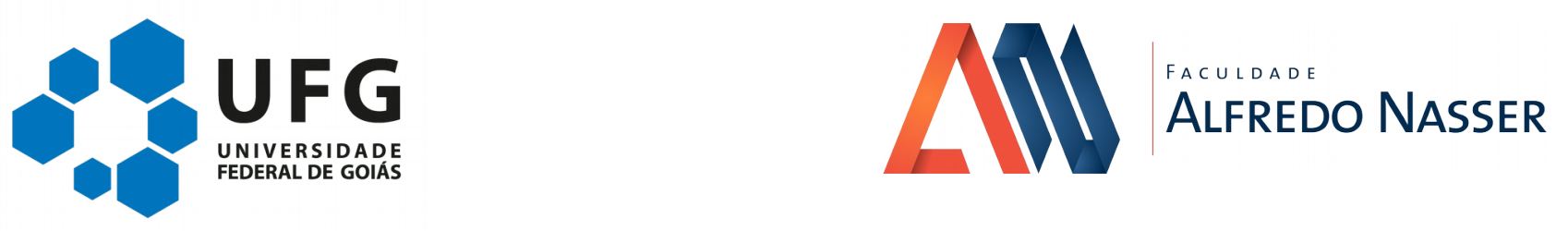

Nome:

Colégio:

Série:

1) O que é DNA?
a) Ácido Desoxirribonucleico
b) Ácido Ribonucleico
c) Dor Nas Articulações
d) Outros
e) Proteína

\section{Gabarito: A}

2) Uma molécula de fita simples caracteriza qual ácido nucléico?
$\checkmark$ DNA
$\checkmark$ RNA
$\checkmark$ Cromossomo
$\checkmark$ Gene
$\checkmark$ Mitocôndrias

Gabarito: B

3) Leia atentamente e considerando seus conhecimentos em Biologia molecular julgue as alternativas abaixo marcando $\mathrm{V}$ para Verdadeiro ou $\mathrm{F}$ para Falso:

( ) Cada cromossomo contém apenas um gene.

( ) A estrutura do DNA consiste em uma longa dupla hélice e o RNA em uma fita única simples.

( ) Moléculas de RNA são constituídas por duas cadeias de nucleotídeos enroladas uma sobre a outra, a chamada "dupla hélice" . 
( ) O DNA é a molécula que transmite a informação genética e tem a capacidade de se autoduplicar.

( ) Uma cópia de DNA é passada para a célula filha durante a divisão celular.

( ) Cada molécula de DNA contém vários "genes" dispostos linearmente ao longo da molécula.

Gabarito: F, V, F, V, V, V

4) Associe as colunas:

\begin{tabular}{|ll|l|}
\hline$\checkmark$ & DNA & $($ ) Base Nitrogenada presente no DNA \\
$\checkmark$ & RNA & $($ ) DNA e RNA \\
$\checkmark$ & Timina & $($ ) Ácido Ribonucleico \\
$\checkmark$ & Ácidos nucleicos & $($ ) Cadeia de aminoácidos \\
$\checkmark$ & Proteínas & $($ ) Ácido Desoxirribonucleico \\
& &
\end{tabular}

Gabarito: III, IV, II, V, I

5) A figura abaixo representa qual ácido nucléico?

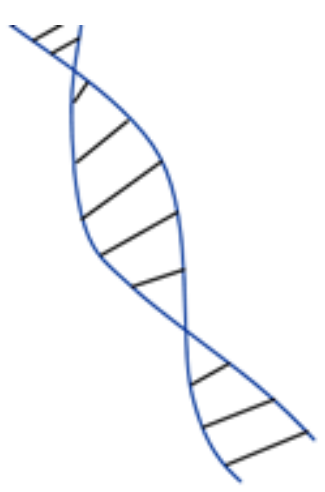

Gabarito: DNA (Ácido

Desoxirribonucleico) 
Apêndice B. Questionário destinado à pesquisa do projeto: "popularização da ciência: desmistificando o dogma central da biologia molecular"
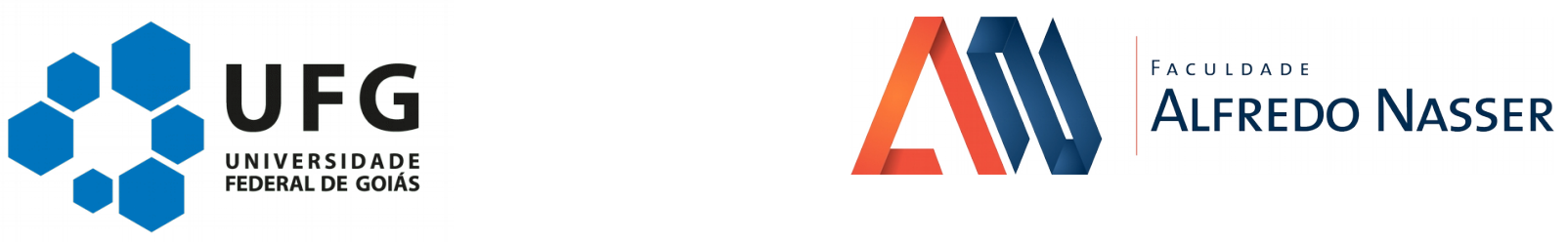

Nome:

Colégio:

Série:

1) Você gostou de visitar o Projeto?

( ) SIM ( ) NÃO

2) Considera que a visita ao Projeto contribuiu para seu aprendizado?

( ) SIM ( ) NÃO

3) Considera que atividades práticas facilitam/melhoram o entendimento dos conteúdos?

( ) SIM ( ) NÃO

4) Sua escola/faculdade proporciona aulas práticas sobre Biologia Molecular? ( ) SIM ( ) NÃO

5) Já teve contato com a Biologia Molecular antes do Projeto?

( ) SIM ( ) NÃO

6) Participaria outras vezes do Projeto?

( ) SIM ( ) NÃO

7) Participaria outras vezes do MOCCA?

( ) SIM ( ) NÃO 
Apêndice C: protocolo para extração caseira de DNA de banana (adaptação de dessen, e.m.b; oyakawa, j.; 2015).

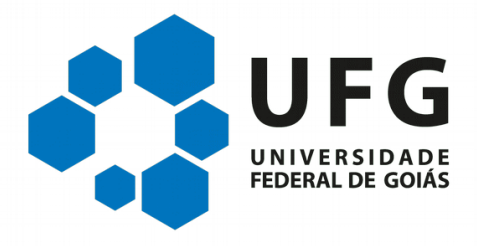

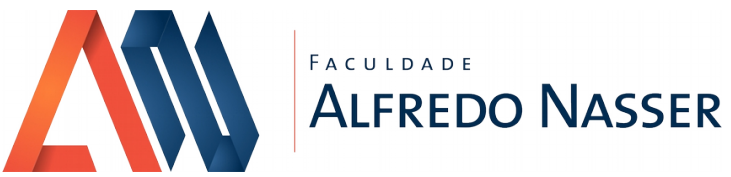

1- Selecionar 1 banana e tirar a casca.

2- Colocar as bananas dentro de um saco plástico e macerá-los pressionando-as com os dedos até obter uma pasta quase homogênea. Transferir a pasta de banana para um copo.

3- Em outro copo misturar $150 \mathrm{ml}$ de água, uma colher (sopa) de detergente e uma colher (chá) de sal de cozinha. Mexer bem com o bastão de vidro, porém devagar para não fazer espuma.

4- Colocar cerca de $1 / 3$ da mistura de água, sal e detergente sobre o macerado de banana. Misturar levemente com o bastão de vidro.

5- Incubar em temperatura ambiente por 30 minutos. Mexer de vez em quando com o mesmo bastão.

6- Colocar uma peneira sobre um copo limpo e passar a mistura pela peneira para retirar os pedaços de banana que restaram.

7- Colocar metade do líquido peneirado em um tubo de ensaio. Colocar apenas cerca de 3 dedos no fundo do tubo.

8- Despejar delicadamente no tubo (pela parede do mesmo), sobre a solução, dois volumes de álcool comum. Não misturar o álcool com a solução. Aguardar cerca de 3 minutos para o DNA começar a precipitar na interfase.

9- Usar um palito de vidro, plástico ou madeira para enrolar as moléculas de DNA. Gire o palito na interface entre a solução e o álcool. 